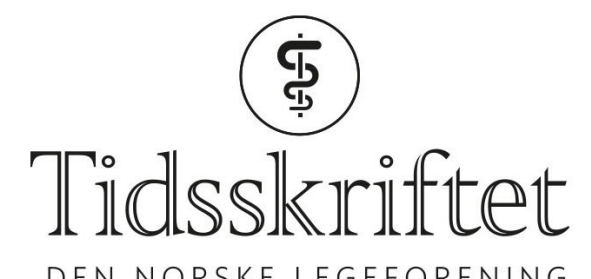

DEN NORSKE LEGEFORENING

\title{
H.V. Holm og medarbeidere svarer:
}

KOMMENTAR

HENRIETTE VEIBY HOLM

E-post: holm.henriette@gmail.com

Henriette Veiby Holm er lege i spesialisering i kirurgi og urologi ved Bærum sykehus. Ingen oppgitte interessekonflikter.

\section{ALV A. DAHL}

Alv A. Dahl er professor emeritus ved Universitetet i Oslo. Ingen oppgitte interessekonflikter.

\section{OLBJØRN HARALD KLEPP}

Olbjørn Harald Klepp er professor emeritus ved Norges teknisk-naturvitenskapelige universitet. Ingen oppgitte interessekonflikter.

\section{SOPHIE D. FOSSA}

Sophie D. Fosså er professor emerita ved Universitetet i Oslo. Ingen oppgitte interessekonflikter.

Vi takker Berg \& Tandstad for kommentaren. De har viktige innspill som vi er helt enige i. Vi anbefaler i artikkelen at pasienter med nydiagnostisert metastatisk prostatakreft henvises tidlig til onkolog for vurdering av induksjonsbehandling med docetaxel. Når det nylig er vist at også abiraterone har en signifikant tilleggseffekt allerede i kastrasjonsfølsom fase (1), er det ytterligere grunn til å få tidlig vurdering av onkolog. Videre mener vi at oppfølgingen av utvalgte pasienter under kastrasjonsbehandling kan skje i samarbeid mellom spesialistog primærhelsetjenesten, hvor pasientene henvises raskt tilbake til spesialist ved tegn til progresjon, som for eksempel PSA-stigning.

\section{LITTERATUR:}

1. James ND, De Bono JS, Spears MR et al. Adding abiraterone for men with high-risk prostate cancer (PCa) starting long-term androgen deprivation therapy (ADT): Survival results from STAMPEDE (NCToo268476). J Clin Oncol 2017; 35: LBA5003. [CrossRef]

Publisert: 21. august 2017. Tidsskr Nor Legeforen. DOI: 10.4045/tidsskr.17.0579

(C) Tidsskrift for Den norske legeforening 2020. Lastet ned fra tidsskriftet.no 